\title{
Learning to co-create the city brand experience
}

\author{
Magdalena Florek \\ Department of Commerce and Marketing, \\ Poznan University of Economics and Business, \\ Poland \\ Magdalena.Florek@ue.poznan.pl
}

\author{
Andrea Insch \\ Department of Marketing, University of Otago, \\ New Zealand \\ andrea.insch@,otago.ac.nz
}

\begin{abstract}
Given the peculiar characteristics of cities, which in many ways render them unamenable to manipulation following the product-concept philosophy, an alternative approach to conceptualising city brands is required. Focus must shift to understanding city brands in terms of how they are experienced and how local authorities can take a leading role in designing and assisting users to co-create valuable city brand experiences. Leading contributions from the theory and practice of the experience economy, service dominant (S-D) logic and consumer brand experiences provide the basis for public and private organisations to devise innovative ways to co-create city brand experiences with city brand users.
\end{abstract}

Received:

December, 2019

1st Revision:

February, 2020

Accepted:

April, 2020

DOI:

$10.14254 / 2071$ $8330.2020 / 13-2 / 12$

Keywords: city brand experience, service-dominant logic, co-creation of value.

JEL Classification: M31, M38

\section{INTRODUCTION}

Place marketing has developed over the past few decades to become an important instrument of urban management for many cities. By implication, cities and their administrators require expertise in place marketing and organizing capacity to inspire and coordinate the various actors involved in the process (van den Berg \& Braun, 1999; Anttiroiko, 2016). The application of place marketing by cities and towns is also an increasing focus of academic research in marketing and urban studies on topics of place branding, especially studies examining the concept of city brands (Gaggiotti, Cheng \& Yunak, 2008; Houghton \& Stevens, 2010; Kavaratzis \& Hatch, 2013). While many scholars emphasise the need to treat 
the marketing of places differently, as a 'special type of marketing', due to the peculiar characteristics of places, theory development in city branding has tended to apply traditional marketing models, with minor adaptations. Yet, perhaps the nature of place branding as a complex, paradoxical process (Dinnie, 2011) typifies the nature of branding in the twenty-first century; ubiquitous, dynamic and contested (Brown et al, 2013). Thus, in the experience economy, place branding theory and practice, like branding in general, is more about the governance of networks of stakeholders, rather than traditional modes of ownership and control-based brand management (Pine \& Gilmore, 1999). The importance of social interactions and dialogue between stakeholders (Kavaratzis \& Hatch, 2013) as the basis for conceptualising users' city brand experiences and for the custodians of the city brand, to curate positive city brand experiences, cannot be understated. Both public and private organisations involved in enhancing the symbolic capital of a place must become facilitators of value co-creation in which a place's users determine the value-in-use of their place brand experiences (Warnaby, 2009).

\section{METHODOLOGY}

The objective of this article is to develop a conceptual framework for understanding the process of city branding as experiences. To build this framework, an integrative review of relevant theoretical approaches is presented, explaining how they inform the conceptualization of city branding as experiences with the implications for theory and practice. Therefore, the city as a product, as a service, and as an experience is investigated in light of major paradigms and approaches in the subject literature. First, the contributions and limitations of the product-centric view and resource-based view are critically discussed. Secondly, the service ecosystem perspective of value co-creation - two fundamental concepts of the service dominant (S-D) view - are presented with its contribution to conceptualising city brands. Finally, the experience economy perspective as applied to place branding and relations between these approaches are discussed. All contributions discussed provide the basis for the conceptual framework which public and private organisations can apply to inspire their thinking to curate mechanisms to co-create city brand experiences with city brand users. Application of the model requires a shift in modes of thinking of those who act as custodians of a city brand, to be open to work with relevant place users to co-create city experiences.

\section{THE CITY AS A PRODUCT: CONTRIBUTIONS AND LIMITATIONS}

Despite a major paradigm shift in marketing theory and practice to service (Vargo \& Lusch, 2004) and experiential (Schmitt, 1999; Pine \& Gilmore, 1998; Grönroos \& Voima, 2013) logics, many municipal authorities and stakeholders in the private sector continue to manage their city as a product. Szromnik (2005) offers an elaborate model of the product-centric approach to accommodate the specificity and complexity of its structure. This conceptualisation, inspired by Levitt's approach to product structure, divides a place's total benefits offered to customers into three parts: 1) the common part (general, appreciated by all target groups), 2) the specific part oriented to selected groups of users of the city's subproducts, and 3) a specialist part related to the special benefits expected by selected individuals and tailored to their exceptional interests. At the core is a universal set of major benefits including a city's basic tangible and spiritual benefits which have potential to be of value to all users who experience a city.

However, defining a city as a product imposes numerous difficulties due to the complexity of the formation and development of a city's inner structure. Unlike traditional products, services, or organisations, a place's assets are inseparably connected, typical of that place and evolve over time; not as a strictly commercial process designed to identify potential users and then refine the product in response to their needs. Van den Berg et al. (2002:7) identify three levels in the structure of a city as a product: level 
1) individual goods and services which can be marketed as a discrete attraction or facility (i.e. an urban product like a museum, a stadium or a shopping centre); level 2) clusters of related goods and services which can be marketed to attract particular targets (a spatial concentration of urban products combined by functional relations, the examples are related to the areas of culture, sport and entertainment); and level 3) the urban agglomeration as a whole or the city itself defined as a superior 'brand' encompassing many urban products. In most cases, the overall structure of a city adjusts over time as the existing features of the city are subsequently adapted to match users' needs and preferences. This pertains predominantly to specific components of a city rather than a territory as a whole (e.g. as a product for tourists). There are some exceptions; cities created as a comprehensive product offering aligned with market needs and local goals (e.g. the capital of Brazil- Brasilia, Las Vegas in the US or Dubai).

A place product is also hard to define unambiguously and permanently because in each case, it has a specific structure consisting of intangible elements like the climate, nature, the inhabitants: their skills, habits, culture, tradition, folk art, language, religion, the local cultural ambience, the entrepreneurial environment etc. Thus, discourse on the concept and management of place brands have questioned the relevance of the product-centric approach and a handful of alternative approaches are proposed (see for example, Kavaratzis \& Hatch, 2013; Giovanardi et al., 2013; Pasquinelli, 2014; Kavaratzis \& Kalandides, 2015). While such conceptualisations have challenged the primacy of the product concept as the basis for conceptualising place brands, they build on pioneering contributions in the field of place marketing of what a place is, including its constituent parts, characteristics and complexity. However, these contributions lack the experience from the users' perspective and how custodians can potentially influence their experience.

Recognising the intangibility of many of these place elements, the resource-based view (RBV) of the firm that emerged in 1980s and 1990s (see Wernerfelt, 1984; Barney, 1986; Barney, 1991; Prahalad \& Hamel, 1990) and its extensions have been embraced by place managers and theorists. This view stresses the importance of unique resources (capabilities and competencies) as the key to creating sustained competitive advantage and in turn performance (Prahalad \& Hamel, 1990). An organisation can be understood as a combination of productive resources - a bundle of tangible and/or intangible resources at its disposal (Wernerfelt, 1984). What distinguishes organisations is the form and combinations of resources they can access and control (Barney, 1997).

Similar to business, resources might be seen as fundamental to city public policy and city branding. Windsperger (2006:20) claims that "locations may realize sustainable competitive advantage, if they offer resources and competencies that are difficult to transfer to and imitate by other locations". Barney (1991) classifies resources into three categories: physical capital resources, human capital resources and organizational capital resources. Overlapping with this classification, intangible assets such as knowledge, values and beliefs have been regarded as resources (Rindova \& Fombrun, 1999). Among the key resources, physical, intellectual and cultural assets seem to be most relevant for cities (Hafeez at al., 2002). Cultural capital as a resource is proposed by Kraaijenbrink \& Groen, (2008:5), which they define as 'the set of values, norms, beliefs, assumptions, symbols, rule sets, behaviors and artifacts that define the actor in relation to other actors and environment' offers additional and useful insights for places as it governs the nature of social interactions within a city's many social networks.

Thus, combining the intangible elements are a place's social networks, made not so much of people but more precisely their contacts and interactions. As Warnaby and Medway (2015:43) explain, 'the place product is co-created through the actions of those within and around it'. So they perceive the city experience as an effect of social interaction within and with the city. These interactions happen, in turn, inside other networks - social, spatial, and infrastructural - which together allow people, things, and information to meet across urban space. For this reason, in the case of places, some researchers, like 
Markowski (2002), refer to a mega product which encompasses a large number and variety of products determining its final shape. Consumption of the mega product is related to the place and results from complex interactions and activities initiated by the users agglomerated in a specific location (Markowski, 2002:112). Despite attempts at standardising a place product in the direction of the combination of unique resources and therefore following the mantra of the product concept, this combination will never be identical within or across specific target groups due to the variable nature of the intangible elements (e.g. the weather, the residents they meet) that influences users' opinions about the place and their satisfaction.

The major contribution of the product-centric logic to conceptualising place brands, informed by the RBV (see Priem \& Butler, 2001a, 2001b), is that it provides the basis for identifying and selecting elements of a city's offering to include in the city brand for various targets audiences (especially in relation to the intangible elements which should constitute the core of the brand). However, this approach does not address many of the challenges of building and securing a city's competitive advantage. One of these challenges is the fact that it is impossible to manage and/or control the city's resources. They belong to cities' communities, and taking the organizational perspective, to particular city stakeholders. Although RBV scholars' focus has recently shifted from resources owned by firms to a relational perspective - the resources that firms' control, or even the ones available to firms - (Gulati, 1998; Dyer \& Singh, 1998) it is still problematic from a city branding perspective. Consequently, products of places can be rather defined as sets of utilities offered for a charge, partly for a charge, or free of charge (on various financial, time and legal conditions) to interested groups of customers.

Another limitation of the product-centric view is that it does not take into account the relations among particular resources. Rather, it focuses on the collection/configuration of resources (i.e. geographic concentration, as explained through cluster theory) (Warnaby, 2009). Since cities are a social construct with all its consequences, they need to be considered as massive social networks. Social interactions occur within social, spatial and infrastructural networks which enable people, things, and information to connect across urban space. These links are crucial in creating a city's brand. Furthermore, the composition of the so-understood place product is also different in time as the city is changing constantly, so are its resources.

Next, if resources are the basis for a city's competitive advantage, a wide place assortment includes elements of various degrees of competitiveness. What is more, each city is characterised by obligatory 'diversity' since cities naturally perform many functions (e.g. all contain both services, classical tangible goods, as well as intangible ones). According to research by Peters et al. (2011), the RBV is best related to niche market products, which a city is not. City branding always requires compromise about which elements from a city's diverse assets are put forward (Boisen et al., 2011) and how they should be integrated (Warnaby, 2009).

The arguments advanced illustrate the many limitations of the product-centric view of cities. A better conceptual understanding of what is being offered by the city brand and consumed in the city is necessary for urban policymakers. Thus, views from services marketing and experiential thinking are assessed for their contribution to build the foundations for conceptualising the city brand from an experiential logic.

\section{THE CITY FROM A S-D LOGIC PERSPECTIVE}

Scholars in branding (Ballantyne \& Aitken, 2007; Merz et al., 2009; Payne et al., 2009) and place marketing have begun to infuse concepts of the service dominant (S-D) view of value creation and delivery (see, for example, Warnaby, 2009; Warnaby \& Davies, 1997; Hankinson, 2007). Akin to Ashworth's (1993) notion that consumers are responsible for assembling their own unique experience, Warnaby (2009:410) argues that place consumers co-create their own value which is 'uniquely and phenomenologically' determined (Akaka \& Vargo, 2015). Following S-D logic, the consumer is an intrinsic 
part of a 'strategic network' (van den Berg \& Braun, 1999) of social and economic actors who interact with the contributory elements of a place, to configure and eventually consume a particular 'bundle of benefits' (Warnaby \& Davies, 1997). In the case of a city's residents, for example, city authorities should ensure that the rich bundle of services (Insch \& Florek, 2008) necessary to co-create an ideal city life are designed and developed with residents (Gehl \& Svarre, 2013).

In every instance that an individual consumes a unique bundle of place benefits, they experience through a process of interaction with others. These interactions are themselves influenced by the institutions and socio-cultural environment (Warnaby \& Davies, 1997; Akaka \& Vargo, 2015) of the place. In such a process, "everyone and everything that comes into contact with the consumer is delivering the service" (Warnaby \& Davies, 1997:209). This view of value co-creation is consistent with the service ecosystems perspective articulated by Vargo \& Lusch (2016), which builds on and extends the context of servicescapes and the servuction model (Langeard et al., 1981; Warnaby \& Davies, 1997). Further, it is appropriate for understanding place and experiences therein as it recognises "...the socio-historic structures (i.e. institutional arrangements) that frame particular places and processes of service exchange" (Akaka \& Vargo, 2015:458). Importantly, all place experiences occur within ecosystems composed of several levels of interaction - micro, meso and macro. Each layer is tied to each other and the determination of value derived from a particular place experience is influenced by the interplay of institutions and interactions at the micro-level and meso-level, nested within the wider socio-cultural and socio-historical contexts.

Adopting the service ecosystem perspective of value co-creation, two fundamental concepts of S-D logic assist in designing valuable and memorable city brand experiences. First, the notion of operant resources (physical, social, knowledge) (Merz et al., 2009) which are attached to a place and are contributed by multiple actors (consumers, governments and agencies, tourism operators etc) to co-create valuable city brand experiences. Thus, an understanding of the specific qualities of these resources and the mechanisms to protect and maintain their intrinsic value on the one hand (i.e. ensure their sustainability) and to communicate their value to individuals who perceive them to be valuable on the other hand (i.e. relevant market segments) is the essential role of place branding. Organisations such as tourism and destination authorities, local government agencies, chambers of commerce are often charged with the role of coordinating the disparate actors in a network to integrate resources and offer various value propositions to potential place customers. Ultimately, such organisations do not have control over the meanings that customers associate with the place brand and similarly have "...little control over the customer's experience of the place "product"' (Warnaby \& Davies, 1997:206). Instead, place brands from an S-D logic can be seen as a form of 'communicative interaction' (Ballantyne \& Aitken, 2007) and serve an important integrating function 'for the complex sets of interactions' in a place (Warnaby, 2009:413). As Aitken \& Campelo, (2011:927) argue, "brand meanings are constantly co-created and re-presented by the community, reflecting, as it does, the everyday experience of its constituents. The resulting brand essence is dynamic, authentic, and, most importantly, collective".

Second, and related to the first concept, is that it is only through interactions among actors that resources are integrated to co-create place brand experiences. Through these myriad interactions, nested in networks of relationships between people, an individual's place brand experience evolves. Consequently, in virtual and real space the interactions between people become a focal element of the model and various methods can be used to investigate the nature of these interactions and in turn the development of relationships (for example, netnography, conversational analysis, observation, diary methods to capture the complete record of interactions in a public space, and forms of behaviour mapping). In the field of urban design and planning, field methods that enable 'small everyday happenings' to be captured and understood are particularly valuable (see, for example, Gehl \& Svarre, 2013). 


\section{THE CITY AS AN EXPERIENCE}

The experience economy perspective implies treating a territory not merely as a production system but also as a valuable stage engaging various producers, intermediaries and consumers as well as different goods and activities in supporting a social performance (Stark, 2011). Lorentzen, Hansen \& Lassen (2007) argue that in the experience economy it is possible even more than ever to "capitalise on places" because it is "place bound" due to particular characteristics arousing feeling, forming identity and involving the customer in a more or less absorbing experience. Cities are the stage for many pure high value experience productions: 1) events such as music festivals, historic festivals, sport events, lectures by highly prestigious people, etc., 2) activities such as shopping, hiking, participating in sport, handicraft or artistic activities attached to the location, etc., 3) services involving experiences including for example the serving of particular foods in theme restaurants, wellness services, exhibitions and art galleries, etc. In addition to being the spaces where such experiences take place, cities are experiences in themselves which can be branded (Lorentzen, Hansen \& Lassen, 2007).

Depending on the discipline and domain, experiences are defined and analysed in their relevant context. Carbone \& Haeckel (1994) defined consumer or customer experiences as "the aggregate and cumulative customer perception created during the process of learning about, acquiring, using, maintaining, and (sometimes) disposing of a product or service" (p. 18). Based on a review of the "state-of-the-art literature on experience marketing," Gentile, Spiller \& Noci (2007:397) present the following definition: "The customer experience originates from a set of interactions between a customer and a product, a company, or part of its organization, which provoke a reaction".

More specifically, Brakus, Schmitt \& Zarantonello (2009:52) define brand experience as "subjective, internal consumer responses (sensations, feelings, and cognitions) and behavioural responses evoked by brand-related stimuli that are part of a brand's design and identity, packaging, communications, and environments". According to Pine \& Gilmore (1999:6) experiences are very powerful tools for building up relations between brands and customers because unlike goods or products, experiences are personal to the buyer and they exist in the minds of people who get involved emotionally, physically and spiritually. While goods are exchangeable and tangible and services tend to be intangible, only experiences are remembered thus making it possible to maintain regular relations with customers. This is again due to the fact that experience is strictly personal and implies the customer's involvement at different levels (rational, emotional, sensorial, physical, and spiritual) (Gentile, Spiller \& Noci, 2007:397). Pine \& Gilmore (1998:97) conclude that since "goods and services become commoditized, the customer experiences that companies create will matter most" and these are experiences that will create lasting value for customers.

Experience is a complicated construct which can be illustrated by its meaning in different languages. In English, experience refers both to lived experiences as well as to the knowledge and expertise gained over time as a result of lived experiences (Schmitt \& Zarantonello, 2013). In German, there are two separate words (very often being analysed in academic discussion in various fields, including Leisure, Tourism, and Marketing; see Duerden, Ward \& Freeman, 2015 for details) which describe lived experiences (erlebnis) and what one gains from these lived experiences (erfahrung) (Highmore, 2002; the first appearance of the terms is probably in a letter by the famous German philosopher Georg Wilhelm Friedrich Hegel). Similarly, in Japanese there are two terms: keiken and taiken (Schmitt, 2011). Some definitions thus refer to the past (referring to knowledge and accumulated experiences over time) and others to ongoing perceptions and feelings and direct observation (Schmitt, 2011).

A term designed to link these two perspectives is structured experiences which describes both the objective, interactive encounters between participants and provider manipulated frameworks (i.e., erlebnis) and the resulting subjective participant outcomes (i.e., erfabrung) of experiences (e.g. Duerden, Ward \& 
Freeman, 2015). "According to this conceptualization, any time a provider (e.g., amusement park, recreation center, fitness trainer, parent) intentionally manipulates some aspect of an experience (e.g., setting, rules, equipment), it would be considered a structured experience" (Duerden, Ward \& Freeman, 2015:603). What is important for cities in this context is the idea that structured experiences are never an individual affair but rather co-created (Rossman \& Schlatter, 2015). And these are places (cities) which are naturally co-created by a large number of stakeholders in both meanings: as a process and as a result. These stakeholders include the very subject of the experience itself as experience is a combination of the social-psychological perspective in which the individual is the sole agent (Kelly, 2009). Cutler \& Carmichael (2010) developed the tourist experience conceptual model of influences and outcomes which includes site elements (e.g., physical, social, product, and service) and interpersonal tourist elements (e.g., motivation, satisfaction, knowledge, memory, perception, emotion, and self-identity).

The link between environmental and personal aspects is crucial as brand experiences arise in a wide variety of settings, where consumers might interact with a brand. Places in general, cities included, do create such settings as they are settings themselves. As Benyon (2014:98) states "all experiences occur in place as to be a person is to be somewhere". In the commercial field, the experiences occur when a consumer interacts for example with a store's physical environment, its personnel, and its policies and practices. Experiences also occur when consumers consume and use products. In other words, experiences are the take-away impressions that customers glean from the various clues (Carbone \& Haeckel, 1994) and clue management includes managing what Carbone (2004) calls the "humanic clues" (e.g. interactions with people) and "mechanical clues" (e.g. environmental design).

This is also valid for cities where the experience with the city brand is defined and affected whenever there is interaction with the city (direct or indirect, following humanic or mechanical clues). These are the so-called brand touch points: all the moments of contact between the city and its 'users'. As such, brand reputation or city strength and robustness are built up experience by experience. This poses a special challenge to city brands as they produce a practically infinite number of touch points. Therefore, there is a need of prioritisation and emphasis given to the identified touch points, crucial from the point of view of a particular place. At the same time, many of them are out of city managers' control (e.g. contact with a member of the local community), which from a managerial point of view creates a difference between city experience and city brand experience. The latter is understood as to be planned, monitored and controlled according to the city branding aims and city brand identity, including communicating brand values and personality. Ideally, both overlap, complement and support one another. This can be achieved if city brand identity captures the real and natural experience of a place. It leads also to an important distinction that can be made between extraordinary experiences and ordinary experiences. Extraordinary experiences are more active, intense, and stylized (Schmitt, 2011) and produce powerful emotional responses and longlasting memories which all brands want to achieve (Arnould \& Price, 1993; LaSalle \& Britton, 2003; Tumbat \& Belk, 2011). Ordinary experiences are also important (Carù \& Cova, 2003), they occur as part of everyday life, they are routine and often result from passive stimulation. While a lot of attention is paid to the design and delivery of memorable experiences, ordinary experiences, and especially a group of ordinary experiences (being connected or complementary and repeated), might have particular relevance for cities (e.g. efficient and timely public transport). Carù \& Cova (2003) suggest that researchers focus on simpler and more contemplative consumption experiences instead of expecting consumers to fill each moment of life with ordinary or extraordinary experiences. Rather than planning experiences for consumers, this view calls for allowing consumers to construct their own experiences (Schmitt, 1999). In the city context, city residents, service providers, local business owners, tourists, and others do create their own experiences, at the same time building experiences for the other groups. These are therefore naturally bottom-up but, should at least be integrated. 


\section{THE CITY BRAND EXPERIENCE - STRUCTURED APPROACH}

The above discussion suggests that a shift in understanding of what the subject of city branding is, is necessary. Rather than focusing on defined city features or assets and related potential benefits, the authors argue that how these are and could be experienced should be the main focus of city brand managers. The authors therefore propose the following structural theoretical model, as shown in Figure 1, which integrates the elements identified in the preceding literature review and derives from the contributions of these particular approaches. According to the proposed model, a city brand is built on the place's resources (as seen in the RBV) and interactions between various actors (S-D logic perspective). Since the city's resource-structure (combination of tangible and intangible assets) enables interactions, they together create a space for experience. Consequently, in that space, city resources and interactions naturally form clues which city users are exposed to and appoint touchpoints which should be integrated and managed. These directly influence both everyday and extraordinary experiences (experiential logic) that people have in places as they are the contact points between the city and its users. As consumption of the city is limited in time and space, the collection of particular touchpoints - situations and places of interactions - are crucial for shaping the city brand. The final experiences being personal to users (and as such the most powerful) have direct influence on how the city is perceived and its brand evaluated.

On this basis, four layers or circles are proposed to represent the process in which the city's resources and interactions within the city form the first contact clues and touchpoints that shape the experiences and finally the perception of the city brand, as brands are built experience by experience. The geocentric structure at the same time suggests how the city brand should be designed and co-created, which requires integration of a city's characteristics in the social environment through interactions, with the possibility of creating various types of experiences. In other words, a city brand is built on various types of experiences people have with a city, which are built on clues and based on city brand touchpoints being managed and delivered, which in turn, derive from the city's resources and interactions within and with the city. City managers should therefore analyse the city's resources from a branding perspective (e.g. which ones have the best marketing potential, level of differentiation included) and existing interactions and relations within them, to determine which clues might be turned into manageable brand touchpoints, and how to use them to create ordinary and extraordinary experiences. This process, if managed effectively, results in the desired way the city is perceived (city brand image). The touchpoints and clues serve in this model as 'translation and simplification' points of various and numerous city assets, the most important to create both types of experiences - ordinary and extraordinary.

The management of the brand touchpoints is an important step in creating the city experience, especially from the external perspective, when contact with a city does not appear on an everyday basis. Based on Aaker's (2013) conceptualization it can be proposed to: 1) identify all existing city brand touchpoints and those that should exist, 2) provide an internal evaluation of all the touchpoints to determine which are managed well and which are deficient in creating experiences, 3) look to past, current, and future target groups to determine which touchpoints have the greatest impact on their experiences, 4) prioritize and balance touchpoints responsible for creating city experiences, and 5) develop an action plan by implementing relevant touchpoints for the experiences. Improving the brand experience at every touchpoint is a way to build a coherent city brand and solidify brand relationships (at the same time as Herezniak, Florek \& Augustyn (2018) show in their analysis of the indicators used by Polish cities' to evaluate the effectiveness of city brand strategy, very few refer to the experience). 


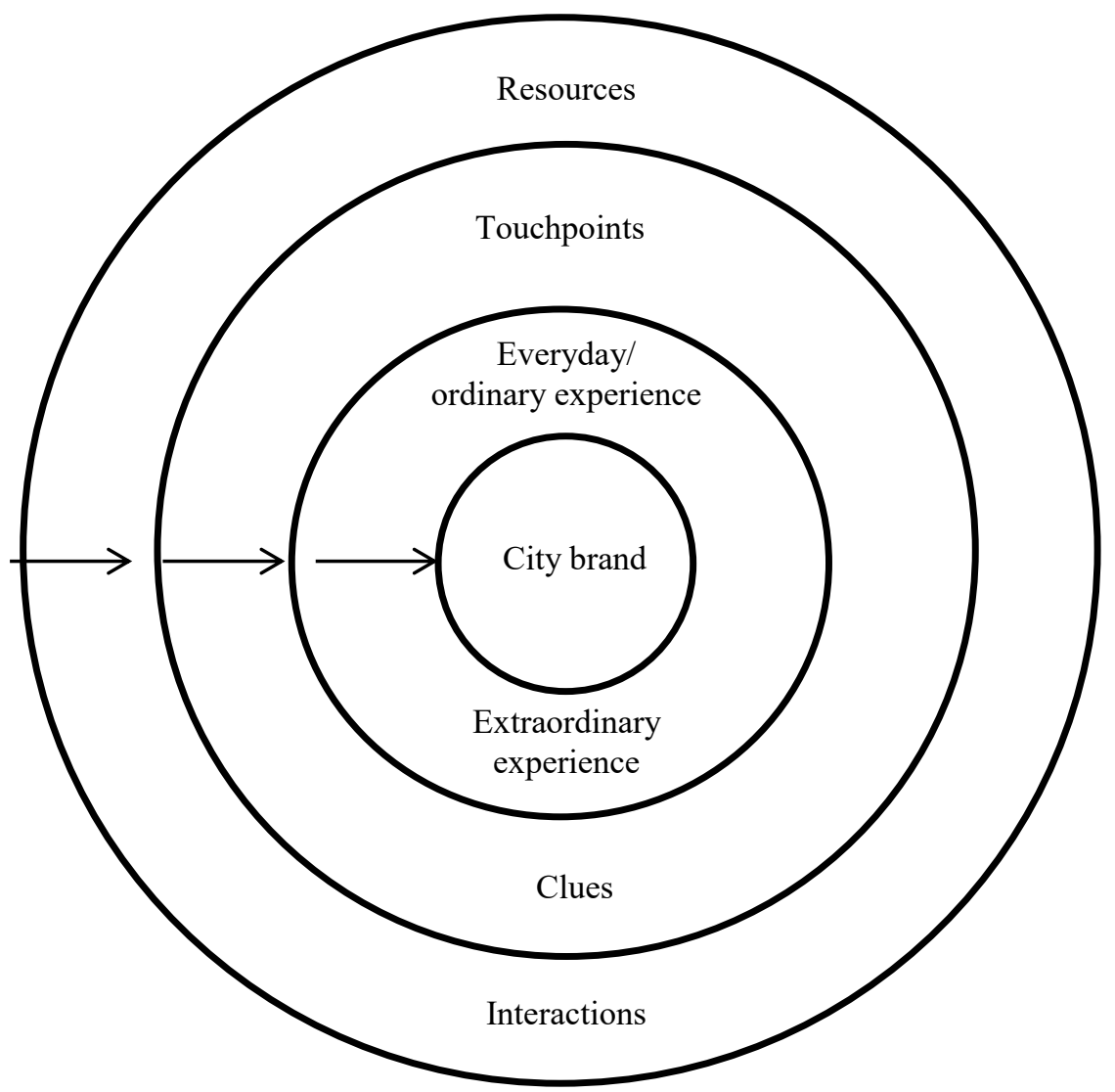

Figure 1. Conceptual model of the city brand - experiential approach Source: own elaboration

To illustrate this logic, for example in leisure tourism, six elements are seen as those building the structured experience (Rossman \& Schlatter, 2015): Interacting People, Physical Setting, Objects (physical, social and symbolic), Structure (rules and program formats that guide interactions), Relationships that participants bring with them into the experience, and Animation (how a program is set into motion and how the action is sustained throughout the program). All these elements, which can be distributed respectively among the layers of the proposed model, finally influence how the place brand is shaped. Thus, the integration and coordination of these elements is crucial as the city brand is co-created and then experienced via the combination of all of them.

This model implies, therefore, that cities are 'produced' and 'consumed' by people who are involved in a more or less absorbing experience; they enjoy the city-bound activities and resources from which experiences come from, such as: particular objects (e.g. historical buildings, museums), events (e.g. concerts, sport events), services (e.g. restaurants, galleries), and diverse social spaces, which let visitors or/and residents interact to enjoy its atmosphere and sociability.

\section{HELSINKI CASE STUDY}

The city of Helsinki was chosen as an instrumental case study of the development of a city brand, following the city council's move in 2015 to brand Helsinki with a mind-set aligned with the co-creation of city brands. Further, the case exhibits several features of experiential thinking in the process of developing and implementing a brand for Finland's capital city. The premise of the city's branding under the "Brand New Helsinki 2020" project was to involve and engage city stakeholders in designing an 
aspirational position for the city, that is, to design "... a vision of what Helsinki wants to be in the future" (Jokela, 2018: 5). Importantly, the city's branding was driven by the need to take a more holistic view of the city and its users, rather than the previous focus on promoting the tourism services of the city undertaken by the Visit Helsinki organisation.

Reflecting the philosophy of city branding as an experiential process, the Helsinki brand concept (Helsinki, 2016b) emphasised "the shared experiences that make up our brand take place wherever and whenever we encounter the city: at events, while travelling, online, through speeches, in customer service situations, and in many other ways". Further, the lived brand experience recognises that "encounters with the city are everywhere. Our brand, Helsinki's reputation, is created constantly, in all kinds of encounters with the city: in public transport, at customer service desks, in schools, travel blogs, city construction site bulletins, outdoor concerts, and much more" (Helsinki, 2016b). The city's branding sought to harness the city's authenticity, functionality and the city's existing assets that are part of its identity (e.g. fascinating contrasts, light summers and dark winters nights). Importantly, the process of rebranding and enabling the city brand experience depended on people - residents, businesses, visitors, and city officials - as cocreators of the brand.

The new brand strategy was developed as an outcome of a collaborative and 'participatory approaches' (Jokela, 2019) designed by the agency responsible for the brand, the City Marketing Unit of the City of Helskini, together with the Kuudes Kerros (Sixth Floor) strategic brand design agency and 20 people representing the brand's steering group. In addition to secondary data sources such as existing reports on Helsinki's resources and brand assets, primary data was collected such as stakeholder workshops, expert interviews, comparative city analyses and assignments undertaken by the steering group, as the basis for the brand concept. Alongside this work, interviews and workshops with different stakeholder groups were conducted to inform the drafting of the initial strategy to align the emerging brand concepts with the tone of voice and medium of communicating about the city brand (Helsinki, 2016c). Specifically, four draft concepts were evaluated and assessed and developed in a number of workshops, events and through feedback obtained via the project's website. Altogether, thousands of people had participated in this project (Helsinki, 2020). After 10 months of work, the Helsinki 2020 brand concept was formally introduced as: the city of people, encounters and actions that make an impact. In summary, it can be stated succinctly as "One Hel of an impact" attitude. However, importantly, the emphasis was placed on actions and not words. Thus, the underlying philosophy of the brand is moving toward one of understanding and enabling the co-creation of Helsinki's brand experience for different types of users. This does not come free of challenges as reported by Jokela (2018: 7) who explains that involving Helsinki's citizens in this process can be difficult. One of the individuals interviewed confessed that one hurdle to be overcome 'has been to reach the Helsinkians and get them to feel that they have ownership; that they are the ones who realize Helsinki's brand'.

To facilitate information sharing and greater participation of stakeholders in co-creating the brand, the City Marketing Unit and later the Communications Division of the City of Helsinki identified a variety of mechanisms for different people, as users of the city brand, to collaborate in sharing their city brand experiences. As the brand concept identities, "different stakeholders experience Helsinki in e.g. the urban environment (all of the city spaces), digital channels, social media, customer service facilities and encounters, city communications and marketing channels, as well as at events and happenings" (Helsinki, 2016c). In addition to the formal primary and secondary means of communicating with target audiences, this approach encourages people to communicate through tertiary channels, particularly through word of mouth and sharing their encounters and experiences of the city through different social media platforms. In particular, for residents of Helsinki, the strategy encouraged Helsinkians to act as ambassadors of the city: "We encourage Helsinkians to share their local knowledge and experiences of their special city". This 
is part of the goal of the city officials, to facilitate a continuous dialogue between the 'city' and its residents. As one example of its execution, an online platform allows people to share their best local experiences of the city and to offer trustworthy recommendations to all users with an interest in the city (MyHelsinki.fi). City officials are viewed as city brand ambassadors too, and many participate in excursions such as seashore yoga sessions, nature trail walks, followed by a discussion and reflection gathering, to identify ways to link these activities and experiences to how they communicate and live the city's brand (Jokela, 2019).

As one group of city users, international visitors were explicitly involved in co-creating the brand experience. The \#HelsinkiSecret Residence campaign was a primarily a tourism marketing campaign to promote the city through locals sharing secrets about the city and later through social influencers (foreign travel bloggers) visiting the city at different times (seasons) of the year and to experience the city as a local would and spread the word throughout their network of followers. This is similar to sponsoring travel writers to visit a city and organising a familial (press-trip tour), with the implicit promise of positive publicity. Visit Helsinki coordinated Helsinki Survival Kits, which included the products and services of 10 local companies, featuring local food, gift cards for use in restaurants, public transport passes and a locally crafted beanie. These packs can serve as cues and stimulus during time spent in the city, as well as 'experience reminders' which can be activate memories of the experience at a later stage (post experience phase) (Dang, 2016). Unlike the traditional press-trip tour, this approach shifted the power to the hands of the travel blogger, enabling them to decide how long they wanted to stay in the city, as well as where they decided to go and what to experience. The role of the official tourism agency, Visit Helsinki, was to offer tools and platforms for the visitors to choose the city experiences that they wanted to do.

A key aspect of the experiential branding of the city is consideration of how different senses play a role. In the case of the \#HelsinkiSecret Residence campaign, the invited travel bloggers were able to listen to Finnish music compiled as part of 8 different play lists by radio Helsinki at their boutique accommodation. According to a member of the campaign's team in research reported by Dang (2016) this creates a "soundscape of the residence. There is a tablet inside the residence having these 8 playlists, so they can get into the mood of Helsinki, by listening to that music". Attention was also given to the other senses, including smell and the different seasons and weather conditions such as snow in the winter and the feel of the forest. The overarching goal of this campaign was to encourage the travel bloggers to be brand ambassadors of the city in a similar way as residents and city officials of Helsinki can be. It is through people and their encounters, interactions and shared experiences that the brand of Helsinki can be co-created in a constantly evolving way.

\section{CONCLUSIONS}

The above discussion and proposed model contribute to the city branding debate on what constitutes the city brand in its broader context. In an era of significant economic and social changes, the experience economy is seen as an integrated approach to formulating city policy and strategic planning (Jacob, 2013; D'Hauteserre, 2013). The movement towards the focus on experience-based city development is likely to involve reoriented public policies, plans and resources as well as new directions for private investments (Hansen \& Lorentzen, 2007:6). An experiential approach to local and urban development and management, and as such branding, requires the involvement of a large number and variety of stakeholders. Building a city brand experience is therefore not exclusive to the marketing department/agency; it requires commitment from the stakeholders and leadership from city authorities. The city manager's role is to coordinate the physical setting, the city resources - from physical to symbolic elements; the relationships and interactions which are developed within and outside the city, in order to 
put them into a 'structure' that will bring the current and potential city users into the experiences. The challenge is however not to lose the authenticity of a place in this process (Zukin, 2010; Boyd, 2012; Wang, 1999).

Another major implication of this shift in thinking is the change required from a one-to-many model of city brand communication to a many-to-many model of social network interactions. This, for example, involves crafting attractive platforms (both virtual and real) for stakeholders to interact to co-create the brand experience. In addition, adopting appropriate methods to understand users' perceptions of their individual city brand experiences (for example, direct observation, unstructured interviews and netnography) is required, so that urban policymakers can better comprehend the nature of 'what is being consumed' (Warnaby \& Davies, 1997:206) and produced.

Places are open organisms, which Govers \& Go (2009) call "the spaces with flows". Thus, a holistic and interdisciplinary perspective of what researchers used to call the 'city product' is necessary in the light of above discussion and contribution of different conceptual perspectives. To broaden and deepen understanding of the foundation of city branding which goes far beyond the critical mass of a city's assets, the authors propose to capture the concept in city experiences, a dynamic approach which takes into account co-creation of city branding processes.

\section{REFERENCES}

Aaker, D. (2013). Five steps to getting brand touchpoints right, https://www.prophet.com/thinking/2013/01/122five-steps-to-getting-brand-touchpoints-right/, accessed 12.05.2017.

Aitken, R., \& Campelo, A. (2011). The four R's of place branding. Journal of Marketing Management, 27(9/10), 913-933.

Akaka, M. A., \& Vargo, S. L. (2015). Extending the context of service: from encounters to ecosystems. Journal of Services Marketing, 29, 453-462.

Anttiroiko, A.-V. (2016). City brands in the mediatised world: economic profiles of Nordic capitals aggregated from city rankings. Scandinavian Journal of Public Administration, 20(2), 97-118.

Arnould, E. J., \& Price, L. L. (1993). River Magic: extraordinary experience and the extended service encounter. Journal of Consumer Research, 20(1), 24-25.

Ashworth G. (1993). Marketing Places: what are we doing? In: Ave G and Corscio F (eds) Urban Marketing in Europe. Turin: Torino Incontra, 643-649.

Ashworth, G.J., \& Voogd, H. (1990). Selling the city: marketing approaches in public sector urban planning. London: Belhaven Press.

Ballantyne, D., \& Aitken R. (2007). Branding in B2B markets: insights from the service- dominant logic of marketing. Journal of Business \& Industrial Marketing, 22, 363-371.

Barney, J. B. (1986). Organizational culture: Can it be a source of sustained competitive advantage?. Academy of Management Review, 11(3), 656-665.

Barney, J. B. (1991). Firm resources and sustained competitive advantage. Journal of Management, 17(1), 99-120.

Barney, J. B. (1997). Gaining and sustaining competitive advantage. Reading, MA: Addison-Wesley.

Benynon, D. (2014). Spaces of Interaction, Places for Experience: Places for Experience. Morgan and Claypool Publishers: San Rafael, United States.

Boisen, M., et al. (2011). "The selective nature of place branding and the layering of spatial identities." Journal of Place Management and Development 4(2), 135-147.

Boyd, J. R. (2012). Authenticity \& Aura: a Benjaminian approach to tourism. Annals of Tourism Research, 30(1), 269289.

Brakus, J. J., Schmitt, B. H., \& Zarantonello, L. (2009). Brand Experience: What Is It? How Is It Measured? Does It Affect Loyalty?, Journal of Marketing, 73(May), 52-68.

Carbone, L. P. (2004). Clued In, New Jersey: FT Prentice Hall.

Carbone, L. P., \& Haeckel, S. H. (1994). Engineering customer experiences. Marketing Management, 3(3), 8-19. 
Carù, A., \& Cova, B. (2003). Revisiting consumption experience: A more humble but complete view of the concept. Marketing Theory, 3(2), 267-286.

Cutler, S. Q., \& Carmichael, B. A. (2010). The dimensions of the tourist experience. In M. Morgan, P. Lugosi, \& J. R. B. Ritchie (Eds.), The tourism and leisure experience: Consumer and managerial perspectives (pp. 3-26). Tonawanda, NY: Channel View Publications.

D’Hauteserre, A. M. (2013). Val d'Europe: a pioneering turn to 'experience' planning? European Urban and Regional Studies, 20(4), 435-446.

Dang, N. (2016). Live Brand Experience in City Branding context: Case study: \#HelsinkiSecret Residence campaign, Bachelor's Thesis, JAMK University of Applied Sciences, Finland.

Dinnie, K. (2011). City Branding: Theory and Cases. London: Palgrave Macmillan UK.

Duerden, M.D., Ward, P., \& Freeman, P. (2015). Conceptualizing Structured Experiences: Seeking interdisciplinary integration. Journal of Leisure Research, 47(5), 601-620.

Dyer, J.H., \& Harbir, S. (1998). The Relational View: Cooperative Strategy and Sources of Interorganizational Competitive Advantage. Academy of Management Review, 23(4), 660-679.

Gaggiotti H., Cheng P.L., \& Yunak O. (2008). City brand management (CBM): The case of Kazakhstan. Place Branding and Public Diplomacy, 4(2), 115-123.

Giovanardi, M., Lucarelli, A., \& Pasquinelli, C. (2013). Towards brand ecology. Marketing Theory, 13(3), 365-383.

Govers, R., \& Go, F. M. (2009). Place branding. Global, virtual and physical identities, constructed, imagined and experienced. London: Palgrave Macmillan UK.

Grönroos, C., \& Voima, P. (2013). Critical service logic: making sense of value creation and co-creation. Journal of the Academy of Marketing Science, 41(2), 133-150.

Gulati, R. (1998). Alliances and Network, Strategic Management Journal, 19(4), 293-317.

Hafeez, K., Zhang, Y.B., \& Malak, N. (2002). Identifying core competence. IEEE Potentials, February: 2-8.

Hankinson G. (2007). The management of destination brands: Five guiding principles based on recent developments in corporate branding theory. Journal of Brand Management, 14, 240-254.

Hansen, C.J., \& Lorentzen, A. (2007). Governance in the Experience-oriented city?. Conference Paper, International conference: Regions in Focus?, April 2007. Lisbon, Portugal.

Helsinki. (2016a). The City of Helsinki marketing strategy 2016-2020, 22/4/2016. Online source, available at http://www.brandnewhelsinki.fi/2020/en/materials/. Accessed 21 January 2020.

Helsinki. (2016b). Helsinki Brand Concept, 22/4/2016. Online source, available at: http://www.brandnewhel sinki.fi/2020//app/uploads/2016/07/01_Helsin ki_brandikonsepti_ENG_web.pdf. Accessed 21 January 2020.

Helsinki. (2016c). Brand New Helsinki, Project description. Online source, available at: http://www.brandnewhelsinki.fi/ 2020//app/uploads/2016/04/BnH_projektin_ku vaus.pdf. Accessed 21 January 2020.

Helsinki. (2020). Helsinki 2020 Project, online, available at: http://www.brandnewhelsinki.fi/2020/en/project/ Accessed 14 January 2020.

Herezniak, M., Florek, M., \& Augustyn, A. (2018). On measuring place brand effectiveness - between theoretical developments and empirical findings. Economics and Sociology, 11(2), 36-51. doi:10.14254/2071-789X.2018/11$2 / 3$.

Highmore, B. (2002). Everyday life and cultural theory: An introduction. New York, NY: Routledge.

Houghton, J.P., \& Stevens, A. (2010). City Branding and Stakeholder Engagement. In K. Dinnie (Ed.), City Branding: Theory and Cases (pp. 45-53). London: Palgrave Macmillan UK.

Insch, A., \& Florek, M. (2008). A great place to live, work and play: Conceptualising place satisfaction in the case of a city's residents. Journal of Place Management and Development, 1(2), 138-149.

Jakob, D. (2013). The eventification of place: urban development and experience consumption in Berlin and New York City. European Urban and Regional Studies, 20(4), 447-459.

Jokela, S. (2018). The development of Helsinki's city brand, Helsinki Quarterly, 2/2018, 15/10/2018, online, available at: https://www.kvartti.fi/en/articles/development-helsinkis-city-brand. Accessed 14 January 2020. 
Jokela, S. (2019). Transformative city branding and the evolution of the entrepreneurial city: The case of 'Brand New Helsinki'. Urban Studies, 1-16, doi:10.1177/0042098019867073.

Kavaratzis, M., \& Hatch, M. J. (2013). The dynamics of place brands: An identity-based approach to place branding theory. Marketing Theory, 13(1), 69-86.

Kavaratzis, M., \& Kalandides, A. (2015). Rethinking the place brand: the interactive formation of place brands and the role of participatory place branding. Environment and Planning A, 47(6), 1368-1382.

Kelly, J.R. (2009). Work and leisure: A simplified paradigm. Journal of Leisure Research, 41(3), 439-451.

Kraaijenbrink, J., \& Groen, A. (2008). Towards a Functional Resource-based Theory of the Firm, Paper presented at the SMS 28th Annual International Conference, Cologne, Germany.

Langeard, E., Bateson, J.E.G., Lovelock, C.H. (1981). Services Marketing: New Insights from Consumers and Managers, Cambridge, MA: Marketing Sciences Institute.

LaSalle, D., \& Britton, T.A. (2003) Priceless: Turning Ordinary Products into Extraordinary Experiences. Boston, MA, Harvard Business School Press.

Lorentzen, A., \& Jeannerat, H. (2013). Urban and regional studies in the experience economy: What kind of turn?, European Urban and Regional Studies, 20(4), 363-369.

Lorentzen, A., Hansen, C.J., \& Lassen, C. (2007). Small cities in the experience economy. An evolutionary approach, Conference Paper, International conference: Regions in Focus?, April 2007. Lisbon, Portugal.

Markowski, T. (2002) Marketing of the city, in: Marketing terytorialny, ed. T.Markowski, Polska Akademia Nauk, Komitet Przestrzennego Zagospodarowania Kraju, Warsaw.

Merz, M.A., He, Y., \& Vargo., S.L. (2009). The evolving brand logic: a service-dominant logic perspective. Journal of the Academy of Marketing Science, 37, 328-344.

Pasquinelli, C. (2014). Branding as Urban Collective Strategy-making: The Formation of Newcastle Gateshead's Organisational Identity. Urban Studies, 51(4), 1-17.

Payne, A., Storbacka, K., Frow, P., \& Knox, S. (2009). Co-creating brands: Diagnosing and designing the relationship experience. Journal of Business Research, 62(3), 379-389.

Peters, M., Siller, L., \& Matzler, K. (2011). The resource-based and the market-based approaches to cultural tourism in alpine destinations. Journal of Sustainable Tourism, 19(7), 877-893.

Pine II, B. J., \& Gilmore, J. H. (1998). Welcome to the Experience Economy. Harvard Business Review, 7-8, 97-105.

Pine II, B. J., \& Gilmore, J. H. (1999). The Experience Economy - work is theatre \& every business a stage, Boston, MA: Harvard Business School Press.

Prahalad, C.K., \& Ramaswamy, V. (2004). Co-creation experiences: The next practice in value creation. Journal of Interactive Marketing, 18(3), 5-14.

Priem, R.L., \& Butler, J.E. (2001a). Is the resource-based "view" a useful perspective for strategic management research?. Academy of Management Review, 26(1), 22-40.

Priem, R.L., \& Butler, J.E. (2001b). Tautology in the resource-based view and the implications of externally determined resource value: further comments. Academy of Management Review, 26(1), 57-66.

Rossman, J.R., \& Schlatter, B.E. (2015). Recreation programming: Designing leisure experiences (7th ed.). Champaign, IL: Sagamore.

Schmitt, B. (2011). Experience Marketing: Concepts, Frameworks and Consumer Insights, Foundations and Trends $®$ in Marketing, 5(2), 55-112.

Schmitt, B.H. (1999). Experiential Marketing. New York, NY: Free Press.

Stark, D. (2011). What's valuable?, in: The Worth of Goods: Valuation \& Pricing in the Economy, ed. J. Beckert, P. Aspers, (pp.319-208). Oxford: Oxford University Press.

Szromnik, A. (2005). The concept of a product in place marketing, in: Marketing terytorialny - możliwości aplikacji, kierunki rozwoju, ed. H. Szulce, M. Florek, (pp.197-208). AE Poznań.

van den Berg, L., Braun, E., \& Otgaar, A.H.J. (2002). Sports and city marketing in European cities. Aldershot, UK: Ashgate Publishing.

van den Berg., L, \& Braun, E. (1999). Urban competitiveness, marketing and the need for organising capacity. Urban Studies, 36, 987-999. 
Vargo, S. L., \& Lusch, R. F. (2016). Institutions and axioms: an extension and update of service-dominant logic. Journal of the Academy of Marketing Science, 44(1), 5-23.

Wang, N. (1999), Rethinking authenticity in tourism experience. Annals of Tourism research, 2(2), 349-370.

Warnaby, G. (2009). Towards a service-dominant place marketing logic. Marketing Theory, 9(4), 403-423.

Warnaby, G., \& Davies, B.J. (1997). Commentary: Cities as service factories? Using the servuction system for marketing cities as shopping destinations. International Journal of Retail \& Distribution Management, 25(6), 204210.

Warnaby, G., \& Medway, D. (2015). Rethinking the place product from the perspective of the service-dominant logic of marketing. In: Retbinking Place Branding Comprehensive Brand Development for Cities and Regions, M. Kavaratzis, G. Warnaby and G. J. Ashworth (Eds.), Switzerland, Springer: 33-50.

Wernerfelt, B. (1984). A resource-based view of the firm. Strategic Management Journal, 5(2), 171-180.

Windsperger, J. (2006). A resource-based view of competitive advantage of cities. Empirical Results on Headquarter Advantages of Vienna in Central Europe. South East European Journal of Economics \& Business, 2, 20-31.

Zukin, S. (2010). Naked City: The Death and Life of Authentic Urban Places. New York: Oxford University Press. 